\title{
Perancangan Sistem Informasi Prosedur Surat Masuk Dan Keluar PT Jasamarga (Persero) Tbk Jakarta
}

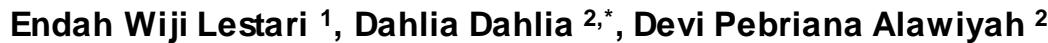 \\ ${ }^{1}$ Rekayasa Perangkat Lunak; Universitas Bina Sarana Informatika; Jl. Kramat Raya No. 98 \\ Senen Jakarta Pusat, Telp. (021) 23231170; e-mail: endah.ewl@bsi.ac.id \\ 2 Sistem Informasi; Universitas Bina Sarana Informatika; Jl. Kramat Raya No. 98 Senen Jakarta \\ Pusat, Telp. (021) 23231170; e-mail: dahlia.dlx@bsi.ac.id, alawiyahdevi07@gmail.com \\ * Korespondensi: e-mail: dahlia.dlx@bsi.ac.id
}

Diterima: 15 Nopember 2021; Review: 02 Desember 2021; Disetujui: 02 Desember 2021

Cara sitasi: Lestari EW, Dahlia D, Alawiyah DP. 2021. Perancangan Sistem Informasi Prosedur Surat Masuk Dan Keluar PT Jasamarga (Persero) Tbk Jakarta. Bina Insani ICT Journal. Vol. 8 (2): 187-196.

\begin{abstract}
Abstrak: Kegiatan surat menyurat ialah kegiatan operasional yang biasa dilakukan setiap orang dalam suatu organisasi atau perusahaan. Pada PT Jasa Marga (Persero) Tbk prosedur pengolahan surat masuk dan keluar saat ini dilakukan secara konvesional baik dalam pembuatan, proses mengelompokan arsip hingga mencari surat. Dalam prosesnya masih ditemui kendala-kendala pada surat itu sendiri ataupun sumber daya manusia yang terlibat didalamnya. Untuk mengatasi masalah yang terjadi pada proses pengolahan surat, maka perusahaan memerlukan sistem yang dapat membantu karyawan dalam proses pengolahannya. Pengelolaan surat yang baik dan terstuktur rapi akan lebih efektif dan efisien untuk proses arsip dan disposisi surat, kurangnya penggunaan media kertas dapat meminimalisir tingkat kesalahan di pencatatan surat, dan mempercepat proses pencarian surat. Sistem pengelolaan surat pada PT Jasa Marga (Persero) Tbk menggunakan metode waterfall yang meliputi proses analisa kebutuhan, desain, pembuatan kode program serta pengujian. Metode perancangan sistem yang dipakai ialah unified modelling language terdiri dari rancangan diagram usecase, diagram aktifitas serta pembuatan diagram relasi. Penelitian ini bertujuan membantu karyawan yang terlibat dalam proses surat masuk dan keluar sehingga proses pengarsipan, disposisi, pencatatan hingga pencarian surat yang dibutuhkan lebih cepat dan akurat.
\end{abstract}

Kata kunci: metode waterfall, prosedur surat masuk, sistem informasi, surat keluar, Unified Modelling Language

Abstract: Correspondence activities are operational activities that are usually carried out by everyone in an organization or company. At PT Jasa Marga (Persero) Tbk, the procedure for processing incoming and outgoing mail is currently carried out conventionally both in the manufacture, the process of grouping archives to finding letters. In the process, there are still obstacles in the letter itself or the human resources involved in it. To overcome problems that occur in the mail processing process, the company needs a system that can help employees in the processing process. Good and neatly structured letter management will be more effective and efficient for the archive and letter disposition process, the lack of use of paper media can minimize the error rate in recording letters, and speed up the letter search process. The mail management system at PT Jasa Marga (Persero) Tbk uses the waterfall method which includes the process of needs analysis, design, program code creation and testing. The system design method used is a unified modeling language consisting of use case diagrams, activity diagrams and relationship diagrams. This study aims to help employees who are involved in the process of incoming and outgoing letters so that the filing, disposition, recording and searching process for the required letters is faster and more accurate. 


\section{Keywords: maximum 5 keywords from paper}

\section{Pendahuluan}

Teknik atau cara yang dilakukan perusahaan atau organisasi dalam menghubungkan kebutuhan pengolahan transaksi di tingkat manajemen untuk pengambilan keputusan dapat disebut juga sebagai sistem informasi [1]. Surat adalah sehelai kertas atau lebih yang ditulis atau diketik dengan menggunakan susunan kalimat yang berisikan berita dari seseorang ke orang lain [2]. Sedangkan Arsip adalah hal penting yang harus diperhatikan dalam kegiatan administrasi dan manajemen di sebuah organisasi, karena arsip merupakan informasi yang tersimpan mengenai semua yang telah dikerjakan sehari-hari [3]. Sarana komunikasi tertulis yang dapat diterima di sebuah perusahaan perorangan ataupun sebuah instansi lain salah satunya berupa surat masuk. Dapat pula diberikan pengertian bahwa surat masuk adalah semua jenis surat yang diterima di instansi lain maupun dari perorangan, baik yang diterima dari pengirim surat dengan menggunakan buku pengirim [4]. Selanjutnya surat keluar merupakan lembaran yang dibuat oleh seseorang atau perusahaan yang tujuannya diberikan kepada perusahaan atau orang lain [5].

PT Jasa Marga (Persero) Tbk, adalah perusahaan yang menjalankan usahanya dalam bidang jalur bebas hambatan yang sampai saat ini dalam pengolahan data Prosedur yang diterapkan dalam pengarsipan surat masuk dan surat keluar masih dilakukan secara konvensional. Dari segi penyimpanan arsip surat hanya dilakukan pencatatan kedalam buku agenda, dengan demikian dibutuhkan waktu lama dalam proses pencarian berkas surat. Adapun masalah lain yang berkaitan adalah penyimpan arsip hanya berupa dokumen dalam bentuk hardcopy yang sangat memungkinkan terjadinya kehilangan. Dengan jaman yang modern ini perkembangan teknologi informasi yang dilakukan perusahaan dengan cara online di internet semakin maju. Kemajuan teknologi informasi ini sangat membantu suatu pekerjaan perusahaan atau instansi kenegaraan, untuk memudahkan prosedur dalam mengirim surat masuk dan keluar secara efektif, efisien, transparan dan akuntabel di lingkungan PT Jasa Marga (Persero) Tbk.

Hasil dari research yang sebelumnya telah dipublikasikan dapat diambil beberapa yang memiliki kesamaan diantaranya. Pada SMK Negeri 1 Magetan pengolahan data masih manual dengan menggunakan lembaran kertas. Proses penyimpanan tersebut memiliki kekurangan seperti rumitnya dalam pencarian berkas serta kemungkinan kertas yang menjadi kusam atau rusak dalam lemari penyimpanan [6].

Dalam Pengelolaan surat di lingkungan kedinasan berikut ini terdapat contoh, pada umunya pengelolaan surat baik surat keluar maupun surat masuk masih dilakukan secara manual mulai dari pencatatan, pengarsipan sampai pada letak arsip. Tingkat kesulitan bagi seorang agendaris dalam membentuk pengelompokkan surat baik surat yang bersifat surat biasa maupun surat yang masuk kedalam kelompok surat penting dan surat bersifat rahasia. Pada metode ini sudah disediakan beberapa macam konsep dari pembuatan surat pengantar, untuk itu agendaris tidak lagi dituntut untuk membuat konsep surat secara manual, sehingga dapat dilakukan proses penyimpanan secara otomatis untuk pembuatan agenda surat masuk dan surat keluar. Dan juga pada metode ini hanya berfocus pada satu konsep yakni surat pengantar, dikarenakan surat pengantar yang akan sering dipergunakan dikantor - kantor lingkungan kedinasan [11].

Ada beberapa pokok permasalahan yang ada di STT Ibnu Sina Batam salah satunya adalah terdapat kesulitan administrasi surat masuk keluar yang belum terstruktur dengan baik yang menyebabkan sering terjadinya surat hilang dan surat yang belum didistribusikan kepada pihak yang terkait. Sukar ditemukan kesulitan dalam pencarian oleh manajemen karena berkas surat tidak dapat diidentifikasikan. Adapun beberapa hambatan lain yang dihadapi antara lain, yang pertama adanya kesulitan pencatatan nomor surat yang terlebih dahulu harus dilakukan pengecekkan didalam buku agenda. Yang kedua proses penyimpanan dokumen secara fisik yang belum efektif dalam hal pencarian berkas surat yang tidak diidentifikasikan oleh sistem pengkodean sebuah file arsip didalamnya. Sehingga pada proses pengiriman surat keluar akan memakan waktu yang lama dan pastinya dengan biaya yang lebih tinggi dikarenakan sebelum surat di kirim kepada penerima surat harus dilakukan penggandaan terlebih dahulu [12].

Pada Kantor Kelurahan surat-surat yang datang selalu terlihat bertumpukan di ruangan dan tidak diolah dengan baik, dengan begitu memungkinkan sering terjadi nya surat rusak atau 
hilang, karena tidak ada penyusunan surat dan tentunya mengganggu kegiatan operasional lainnya. Maka dari itu diperlukan proses perapihan agar seluruh kegiatan operasional yang terjadi pada kantor kelurahan berjalan dengan lancar dan proses penyampaian informasi memakan waktu yang lebih singkat [13].

Administrasi arsip dan olah surat yang berjalan pada pada SMP Negeri 32 Pekanbaru memiliki beberapa masalah, salah satunya ditemukan kesuliatan dalam pencarian arsip surat masuk dan keluar apabila dibutuhkan dalam waktu cepat akan sangat memakan waktu dalam hal pencarian surat dikarenakan banyaknya penumpukkan dan tidak tersimpan dengan baik selembaran surat masuk dan surat keluar, kemungkinan akan terjadinya arsip surat menghilang juga akan sangat riskan dikarenakan belum ada cara yang efektik dan efisien dalam hal pencarian arsip surat masuk dan juga arsip surat keluar. Dari permasalahan yang terjadi ini maka ditemukan solusi untuk memperbaiki dan meminimalisir tingkat permasalahan tersebut dengan penggunakan sebuah aplikasi pengarsipan berbasis web. Dengan aplikasi yang sudah menngunakan web ini maka akan lebih mudah pengambilan arsip ataupun pengelolaan arsip lebih efektik dan efisien karena bisa terjangkau kapan saja dibutukan arsip - arsip surat masuk dan surat keluar [14].

\section{Metode Penelitian}

Model pengembangan perangkat lunak pada penelitian ini menggunakan model waterfall [7] yang terdiri dari beberapa tahapan diantaranya:

\section{Analisis Kebutuhan}

Dalam menganalisa kebutuhan dilakukan tahapan pengumpulan dari kebutuhan yang akan diimplementasikan lebih intens dan mendalam untuk mengelompokkan kebutuhan akan perangkat lunak yang seperti apa yang akan dipergunakan oleh user. Untuk itu pemilihan spesifikasi akan perangkat lunak ini perlu diadakan dokumentasi.

\section{Desain}

Desain adalah tahap yang diperlukan untuk menggambarkan sebuah perangkat lunak yang di fokuskan pada pembuatan data terstruktur, rancangan arsitektur, menjabarkan kebutuhan analisa nya dan menunjukan hasil paparan desain yang telah dibuat untuk diterapkan menjadi program pada tahap selanjutnya menggunakan Sublime Text 3, database MySQL.

\section{Pembuatan Kode program}

Pembuatan kode program merupakan suatu kegiatan yang merealisasikan sebuah rancangan sistem menjadi sistem yang dapat digunakan dengan PHP, HTML, CSS, dan Java Script.

\section{Pengujian}

Tahap pengujian dilakukan untuk menghindari dan meminimalisir tingkat terjadi error program pada saat pengimplementasian program dari logika sebuah program dan fungsi-fungsi dari semua bagian struktur pemrogramnnya. Selain daripada tahapan pengujian hal tersebut juga dilakukan untuk menunjukkan semua output yang dihasilkan sesuai dengan yang dibutuhkan. Berikut adalah proses bisnis yang berjalan dalam proses surat masuk dan keluar pada PT Jasa Marga (Persero) Tbk diantaranya:

\section{Prosedur Surat Masuk}

Karyawan divisi B akan menerima surat dari karyawan divisi A, kemudian karyawan divisi B menyerahkan surat tersebut ke sekretaris manager, sekretaris manager akan memeriksa surat dan menulis dibuku agenda kemudian dilakukan pengisian lembar disposisi, setelah lembar disposisi diisi, surat tersebut diserahkan kepada General Manager untuk dilakukan acc kembali, dan dikerjakan sesuai dengan agenda informasi dari isi surat yang tersedia.

\section{Prosedur Surat Keluar}

Karyawan Divisi A membuat surat sesuai perintah dari General Manager, setelah surat tersebut selesai dibuat dan surat yang sudah ditulis informasinya di serahkan ke sekretaris manager, dan akan diserahkan ke General Manager. Jika surat tidak layak maka surat akan 
kembali diserahkan kepada karyawan untuk di revisi, jika surat layak maka surat akan segera ditandatangani dan dicap oleh General Manager, dan diserahkan kembali kepada karyawan untuk diberikan kepada divisi yang bersangkutan sesuai dengan data surat tersebut.

\section{Prosedur Pengarsipan}

Divisi terkait surat akan diserahkan kepada petugas arsip, dan petugas arsip menerima surat dan akan diarsipkan berdasarkan kode atau klasifikasi. Berikut akan dijelaskan rancangan yang telah dibuat untuk menggambarkan prosedur yang sedang berlangsung saat ini pada perusahaan dalam sebuah diagram yang biasa disebut diagram aktifitas. Pada diagram aktifitas ini rancangan prosedur sistem dimulai pada tahap proses surat keluar dimana divisi karyawan akan membuat surat keluar dan menyerahkan ke sekretaris, kemudian sekretaris menyerahkan surat ke general manager untuk proses tanda tangan dan cap surat jika disetujui, jika tidak maka surat dikembalikan ke divisi karyawan. Kemudian proses surat masuk, pertama-tama divisi karyawan menerima surat masuk yang kemudian surat tersebut akan di serahkan ke bagian sekertaris untuk diperiksa dan diagendakan oleh sekretaris. Skretaris akan mengisi lembar disposisi dan menyerahkan surat ke general manager untuk proses acc surat. Yang selanjutnya adalah proses pengarsipan yang dilakukan oleh divisi karyawan untuk menyerahkan surat ke petugas arsip, setelah itu petugas arsip akan mengarsipkan surat sesuai klasifikasi surat nya masing-masing.

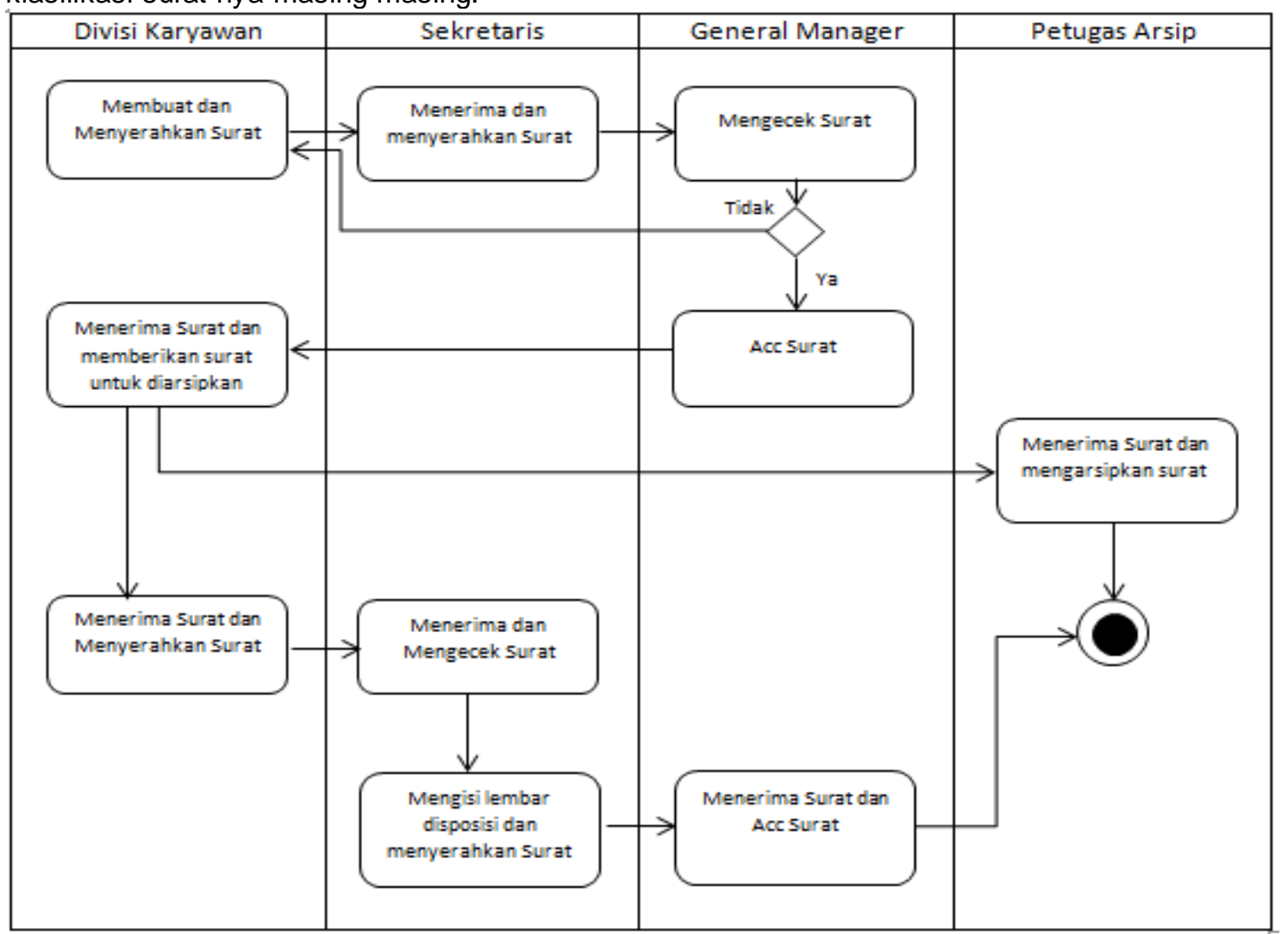

Sumber: Hasil Penelitian (2021)

Gambar 1. Activity Diagram Pengelolaan Surat

\section{Hasil dan Pembahasan}

\section{Analisa Kebutuhan Sistem}

Berdasarkan kebutuhan sistem pengguna (user) dibutuhkan menganalisa dan mengidentifikasikan. Berikut diantaranya adalah: untuk masuk kedalam sistem, maka diperlukan login atau memasukan data username dan passwordnya, diperlukan hal tersebut agar rahasia dari masing-masing user dapat terjaga dengan baik. Divisi menginput surat keluar ke sistem. Sistem mencetak tanda bukti surat. 
Kebutuhan divisi adalah sebagai berikut divisi dapat melakukan login dan logout, divisi dapat menginput surat keluar, divisi dapat menerima notifikasi surat masuk, divisi dapat melihat arsip, divisi dapat mengirim surat atau mencetak surat.

Kebutuhan Sekretaris adalah sebagai berikut Sekretaris dapat melakukan login dan logout, Sekretaris dapat menginput surat keluar, Sekretaris dapat menerima notifikasi surat masuk, Sekretaris dapat mendisposisikan surat, Sekretaris dapat melihat arsip, Sekretaris dapat mengirim atau mencetak surat.

Pada use case diagram akan memberikan informasi mengenai keterkaitan dari sistem informasi yang akan dibuat berdasarkan pola dari sebuah interaksi dari satu aktor atau lebih menurut pandangan dari Rosa dan Salahudin [8]. Bentuk dari rancangan sistem usulan surat masuk dan keluar pada PT Jasa Marga (Persero) Tbk dalam bentuk Use Case Diagram adalah sebagai berikut:

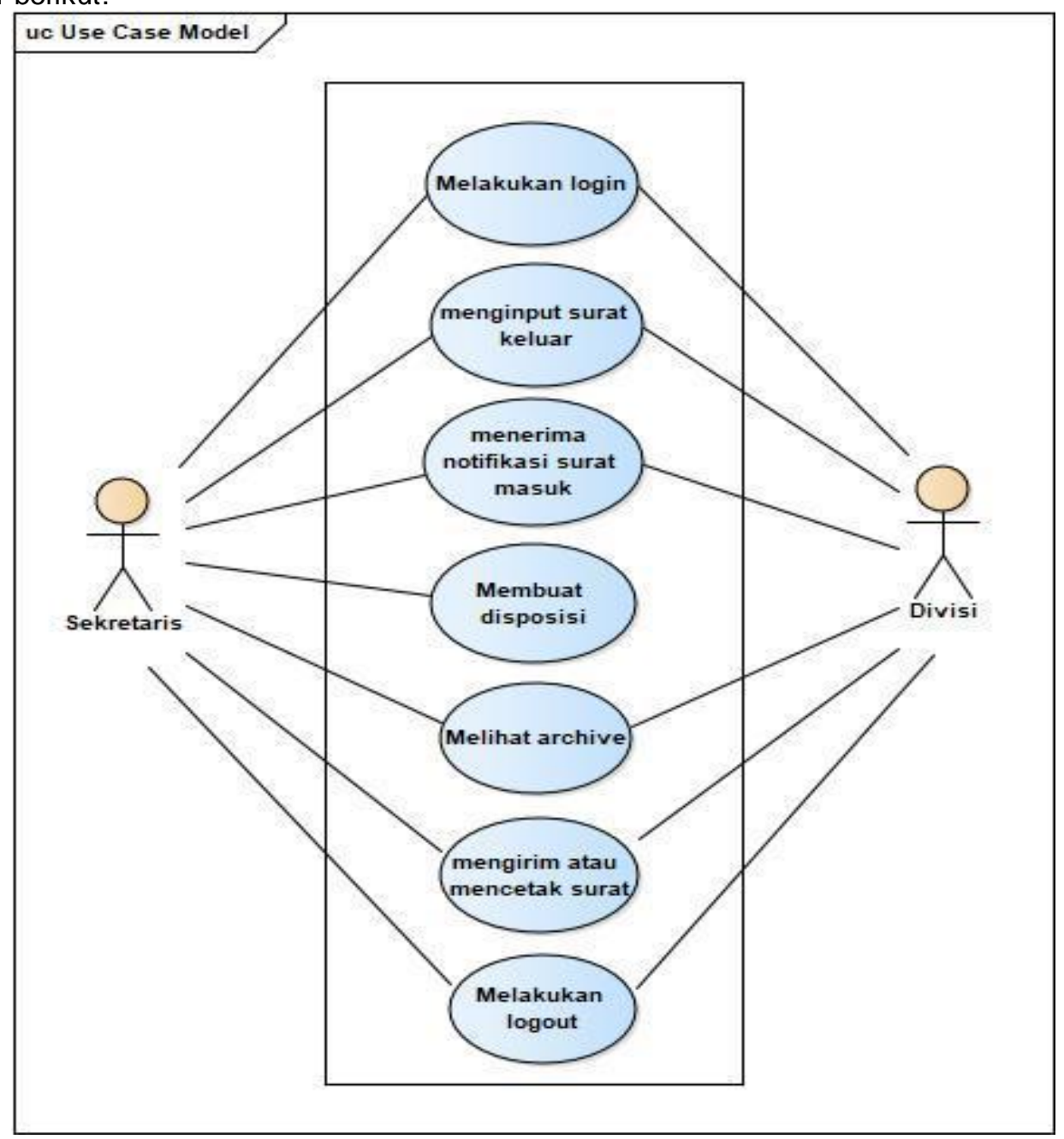

Sumber: Hasil Penelitian (2021)

Gambar 2. Diagram Use Case Surat Masuk dan Keluar

Activity Diagram adalah kumpulan diagram yang didalamnya memperlihatkan proses yang dijalankan oleh aktor, menurut Rosa dan Salahudin dalam [9]. Gambaran berikut adalah rancangan diagram aktifitas yang dibuat untuk menggambarkan bagaimana usulan sistem informasi yang akan dibuat dalam pengembangan sistem manual menjadi sistem yang terkomputerisasi. Adapun activity diagram sistem informasi prosedur surat masuk dan keluar pada PT Jasa Marga (Persero) Tbk sebagai berikut:

Activity diagram surat masuk, dimana aktifitas dimulai oleh user seperti divisi atau sekretaris memilih menu surat masuk. Kemudian sistem akan menampilkan form surat masuk. Kemudian user akan klik notifikasi surat masuk, jika ingin dicetak maka klik menu cetak dan sistem akan memproses pencetakan dokumen. 


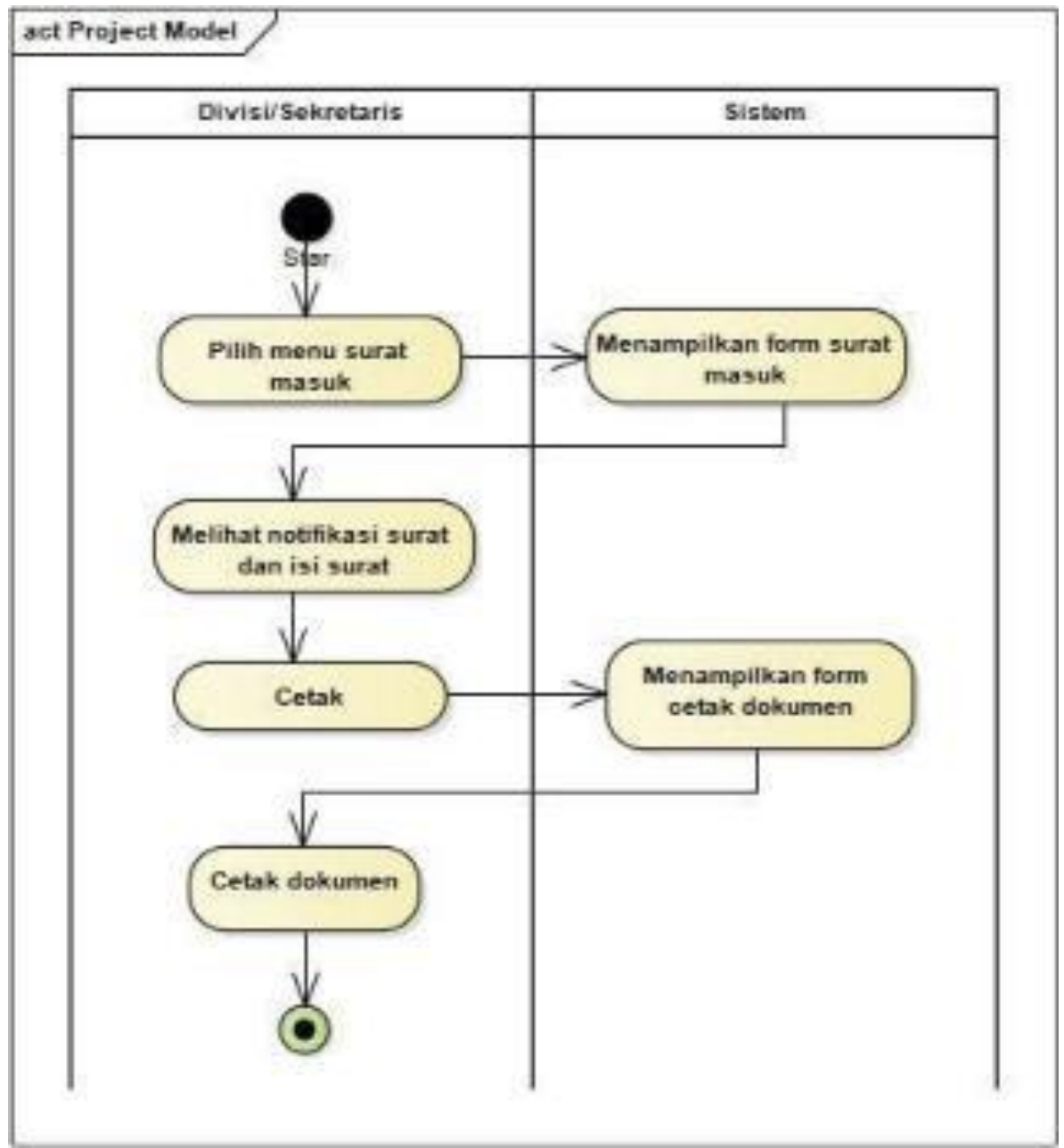

Sumber: Hasil Penelitian (2021)

Gambar 3. Activity Diagram Usulan Surat Masuk

Selain diagram aktifitas surat masuk, tentunya ada beberpa rancangan diagram yang dibuat untuk menggambarkan proses usulan berjalannya sistem, namun dalam kata-kata nya akan dijelaskan sebagai berikut : activity diagram surat keluar, aktifitas dimulai oleh user seperti divisi atau sekretaris memilih menu surat keluar, sistem menampilkan form surat keluar. Kemudian user akan input surat keluar, jika ingin dikirim maka user bisa klik menu kirim dan kemudian sistem akan mengirimkan surat. Jika ingin dicetak, maka user bis klik menu cetak dan kemudian sistem akan menampilkan form cetak dokumen.

Proses disposisi surat, user yang melakukan proses ini adalah sekretaris dengan memilih menu lembar disposisi, kemudian sistem akan menampilkan lembar disposisi, sekretaris akan memmilih klasifikasi arsip dan bisa melakukan cetak atau kirim berkas disposisi. Jika tekan menu kirim, maka disposisi surat akan dikirim oleh sistem dan jika cetak maka sistem akan menampilkan cetakan dokumen.

Satu lagi adalh Proses pengarsipan surat yang dilakukan oleh user sekretaris atau divisi. Sistem akan menampilkan menu arsip setelah dipilih oleh user pada sistem, kemudian user memilih arsip yang dibutuhkan dan bis dilakukan proses pencetakan juga dengan klik menu cetak, kemudian sistem memperlihatkannya di layar komputer siap cetak.

Pembahasan berikut nya yang akan dibahas adalah mengenai ERD atau Entity Relationship Diagram merupakan sesuatu model atau tekhnik pendekatan yang dapat menjabarkan suatu hubungan entity didalam sebuah sistem, yang mana hubungan tersebut dijelaskan sebagai one-to-one, one-to-many, many-to-one dan many-to-many menurut Rossa dan Shalahuddin, dalam [10].

Di dalam Diagram ini menjelaskan relasi entitas satu dengan yang lainnyar. Dimana terdapat empat buah entitas yaitu surat masuk, surat keluar, user dan disposisi. Setiap user 
BINA INSANI ICT JOURNAL ISSN: 2355-3421 (Print) ISSN: 2527-9777 (Online); 187 - 196

dapat menginput surat masuk, menginput surat keluar dan mengelola disposisi. Entitas surat masuk memiliki atribut seperti nomor_sm, asal_surat, perihal, klasifikasi_arsip, masa_retensi_surat, isi_surat, tgl_terima, cari, jenis_surat, kepada dan id_user sebagai kunci tamu, sedangkan kunci utama pada entitas surat_masuk adalah nomor_sm.

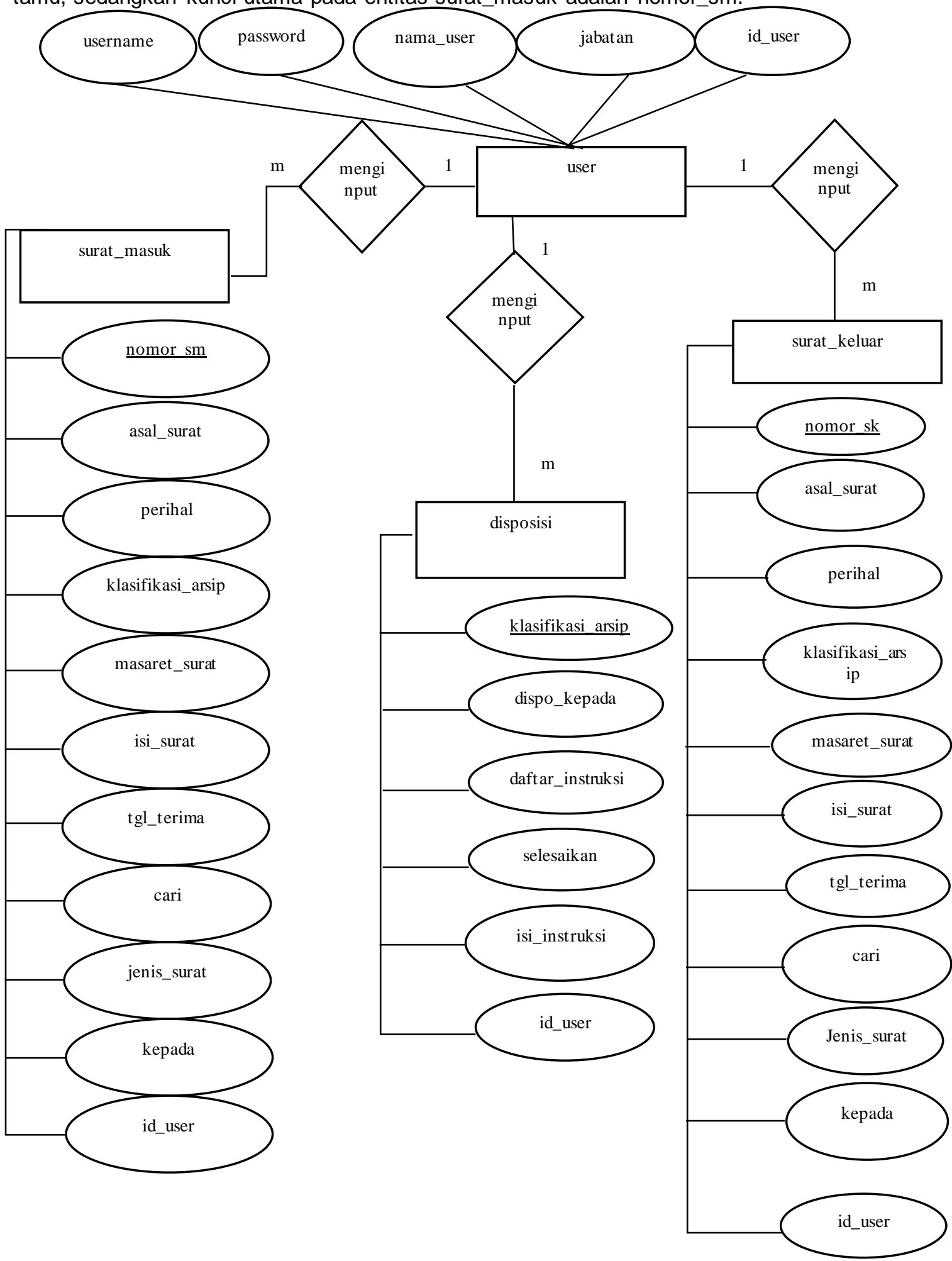

Sumber: Hasil Penelitian (2021)

Gambar 4. Usulan Entity Relationship Diagram 
Selanjutnya ada entitas surat keluar yang terdiri dari atribut nomor_sk sebagai kunci utama, asal_surat, perihal, klasifikasi_arsip, masa_retensi_surat, isi_surat, tgl_terima, cari, jenis_surat, kepada dan yang menjadi kunci tamu adalah id_user. Yang ketiga ada tabel disposisi memiliki atribut klasifikasi_arsip, disposisi_kepada, daftar_instruksi, selesaikan, isi_instruksi, dan id_user sebagai foreign key. Terakhir yaitu entitas user berisikan atribut username, password, nama_user, jabatan dan id_user sebagi primary key.

Relasi yang terjadi antara tabel user dan surat masuk adalah one to many karena 1 user dapat menginput banyak surat masuk. Hubungan yang berikutnya terjadi pada tabel user dan surat keluar dengan relasi one to many karena banyak surat keluar dapat di akses oleh satu user. Antara tabel disposisi dan user pun terjadi relasi one to many dimana satu user dapat melakukan lebih dari satu disposisi surat.

Tabel surat masuk berisikan atribut yang diperlukan dalam penyimpanan data surat masuk, salah satu atribut nya adalah nomor_sm yaitu jika dijelaskan maksudnya adalah untuk menggambarkan nomor surat masuk, karena setiap surat masuk memiliki nomor yang berbedabeda. Begitupun dengan tabel surat keluar yang memiliki atribut hampir sama dengan atribut didalam entitas surat masuk, karena isi surat nya pun sebenarnya sama jadi atribut yang terbentuk juga sama namun yang membedakannya adalah kunci utamanya yakni nomor_sk atau nomor surat keluar. Tabel disposisi berisikan data surat yang akan disposisikan tujuan nya kemana yang memiliki klasifikasi_arsip sebagai primary key, tentunya diikuti dengan atribut id_user sebagai kunci tamu didalam tabel disposisi. Sedangkan tabel user berisikan data user yang mengelola surat tersebut, username yang dijadikan primary key harus memiliki keunikan agar tidak sama satu dengan yang lainnya. Jadi jika terjadi kesalahan maka dapat dipertanggungjawabkan oleh user yang menangani hal demikian.

Yang perlu diperhatikan dalam pembuatan diagram relasi selain hubungan kardinalitasnya adalah penamaan atributnya, seperti tidak boleh adanya spasi dalam penamaan atribut, kemudian pembarian nama pada setiap atribut yang menjadi kunci utama pun sebaiknya dihindari memiliki nama yang sama, mengapa demikian agar saat proses relasi nanti tidak terjadi duplikasi data yang sama. Maka dari itu untuk nomor surat di bedakan jenis nya, seperti apakah surat tersebut adalah surat masuk atau surat keluar. Dalam pembuatan program apapun sebaiknya yang dilakukan pada tahap pertama adalah menganalisa kebutuhan sistem nya seperti apa, tahap menggambar diagram relasi ini juga termasuk dalam tahap analisa, dimana penulis melakukan analisa tabel apa sajakah yang dibutuhkan dalam sistem yang akan dikembangkan nanti. Setelah menentukan tabel, maka seorang perancang program juga harus menganalisa atribut apa yang digunakan didalam masing-masing tabel, tentunya akan lebih mudah jika dapat melihat fisik dokumennya. Itulah mengapa disetiap rancangan sistem informasi membutuhkan contoh bentuk dokumen masukan dan keluaran yang ada pada suatu perusahaan, agar mempermudah pengolah sistem untuk membuat rancangan diagram relasinya.

\section{Hasil}

Hasil yang diharapkan dari perancangan sistem informasi pengelolaan surat pada PT Jasa Marga (Persero) Tbk adalah membuat sistem pengolahan surat lebih baik, dengan mengurangi penggunaan kertas dalam proses surat menyurat membuat proses surat masuk dan keluar lebih efisien. Dengan penggunaan sistem surat masuk dan keluar pada perusahaan juga dapat mengurangi kesalah saat proses pengarsipan berkas surat, baik berkas surat masuk ataupun surat keluar. Mengurangi tumpukan lembaran surat pada lemari arsip juga dapat membantu petugas dalam proses penyeleksian surat yang wajib dicetak atau tidak, sehingga kerusakan dan kehilangan berkas surat yang telah dicetakpun dapat seminimal mungkin ditemukan. Proses pencarian surat masuk dan keluar, bisa lebih cepat dengan adanya menu pencarian dalam sistem. Dengan adanya sistem pada proses surat masuk dan keluar pun dapat meminimalisir sumber daya manusia yang terlibat didalamnya. Dibawah ini adalah rancangan website prosedur surat masuk dan keluar pada PT Jasa Marga (Persero) Tbk.

Dibawah ini adalah tampilan sistem informasi yang dibuat, dimana pada halaman ini menampilkan menu surat masuk, surat keluar, beranda, lembar disposisi, archive dan logout salah satu contoh yang ditampilkan dibawah ini adalah Halaman Surat Masuk. Pada halaman ini user akan melakukan proses surat masuk dengan klik menu surat masuk. User dapat klik notifikasi surat untuk melihat detail isi surat. Terdapat pula menu search yang dapat digunakan oleh user untuk mencari surat masuk. 
Berikutnya pada menu surat keluar user dapat memilih dengan klik menu surat keluar. Setelah user input data surat keluar, maka surat dapat dikirim dengan klik tombol kirim atau klik cetak untuk mencetak surat. Pada halaman arsip user akan melakukan proses disposisi surat dengan klik menu arsip. Setelah user input data surat yang ingin diarsipkan, maka surat dapat diarsipkan dengan klik tombol kirim atau cetak dengan klik tombol cetak.

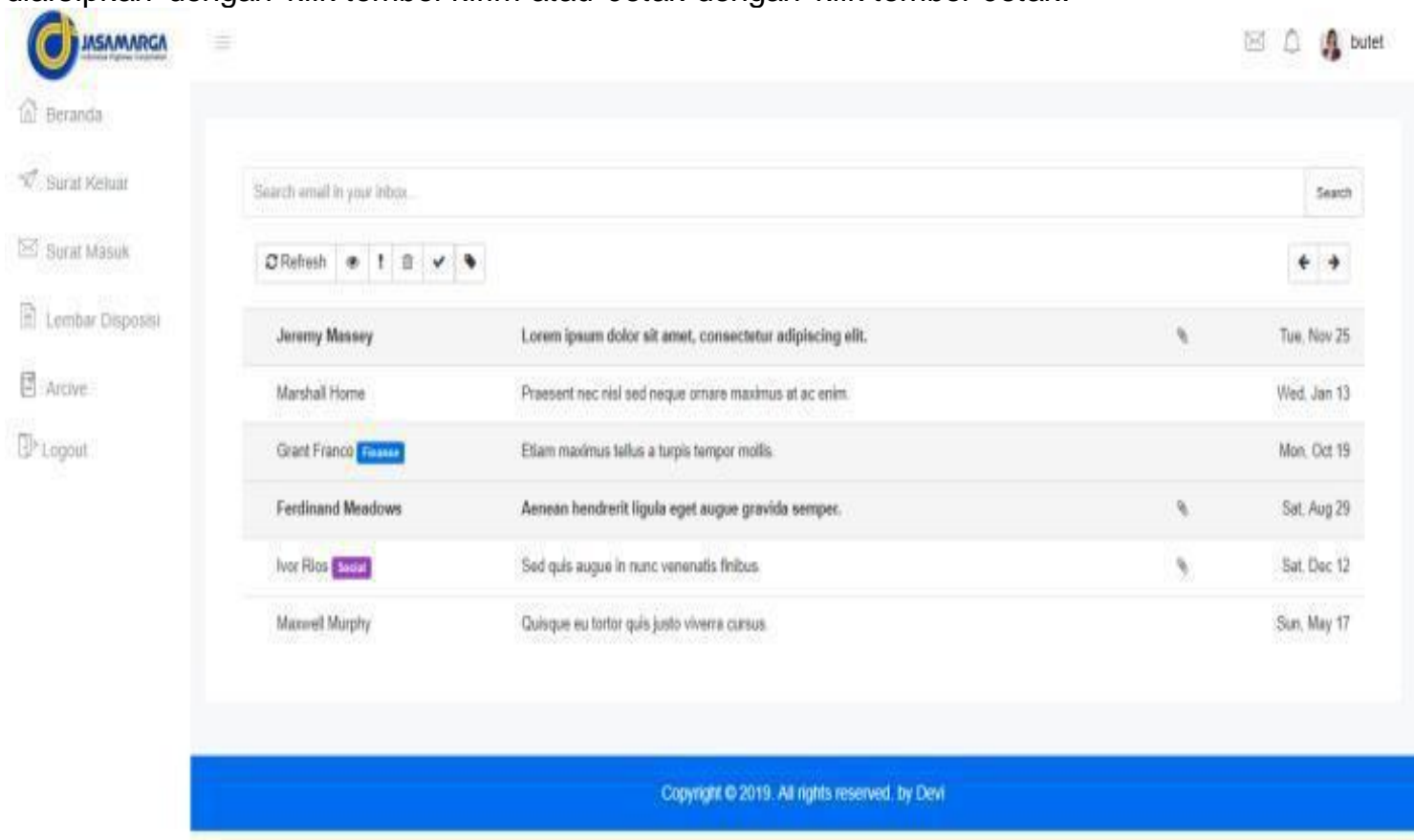

Sumber: Hasil Penelitian (2021)

Gambar 5. Halaman Surat Masuk

\section{Kesimpulan}

Berdasarkan dari hasil perancangan sistem tentang sistem informasi surat masuk dan surat keluarr yang diusulkan, maka penulis dapat menarik kesimpulan berikut, dengan adanya perancangan web ini, maka pengelolaan data surat menjadi lebih efisien, dimana karyawan dapat langsung menginput surat masuk dan keluar pada sistem. Untuk pengecekan surat masuk, jika terdapat banyak surat masuk, maka karyawan dapat menggunakan menu search dalam pencariannya, dengan adanya menu tersebut membuat proses pencarian menjadi lebih cepat. Karyawan dapat mengetik surat langsung pada menu surat keluar, kemudian dapat mencetak surat tersebut jika diperlukan untuk dicetak dengan menggunakan menu cetak. Untuk proses pengiriman surat setelah surat selesai diketik, karyawan dapat menggunakan menu kirim untuk mengirim surat. Dengan adanya sistem, proses pengarsipan surat pun menjadi lebih mudah dengan sebelumnya dapat memastikan apakah surat tersebut wajib dicetak atau tidak. Jika surat wajib dicetak, maka surat tersebut nanti nya masih dapat disimpan di lemari arsip, namun jika surat tersebut hilang, pada sistem tentunya masih tersedia bentuk softcopynya.

\section{Referensi}

[1] E. Y. Anggraeni and R. Irviani, Pengantar Sistem Informasi. Yogyakarta: Andi Offset, 2017.

[2] S. Hidayat and U. Jumiatin, "Prosedur Pengelolaan Surat Untuk Memperlancar Proses Penyampaian Informasi Pada Kantor Kecamatan Pamulang," J. Sekr., vol. 3, no. 1, p. 90, 2016.

[3] M. Dedi Irawan and S. A. Simargolang, "Implementasi E-Arsip Pada Program Studi Teknik Informatika," J. Teknol. Inf., vol. 2, no. 1, 2018.

[4] D. L. Rahmah, "Perancangan Aplikasi Sisitem Perpustakaan Berbasis Web Pada PT. Dwi Pilar Pratama," Fakt. Exacta, vol. 3, pp. 282-292, 2014.

[5] J. A. Prawono and A. R. Pamungkas, "Sistem Informasi Pengelolaan Surat Masuk Dan Surat Keluar di STMIK AUB Surakarta," Informatika, vol. 2, no. 1, pp. 26-33, 2015. 
[6] F. Masykur, I. Makruf, and P. Atmaja, "Sistem Administrasi Pengelolaan Arsip Surat Masuk Dan Surat Keluar Berbasis Web," Indonesian Journal on Networking and Security, vol. 4, no. 3, pp. 1-7, 2015.

[7] S. Rosa, Rekayasa Perangkat Lunak. Bandung: Informatika, 2013.

[8] E. W. Lestari and N. Yani, "Perancangan Pembelajaran Daring SMK PGRI 1 Jakarta," Jurnal Komputer dan Informatika, vol. 21, no. 1, pp. 9-16, 2019.

[9] E. W. Lestari, F. Ramdani, R, "Sistem Informasi Pelayanan Jasa Cuci Kendaraan Bermotor Berbasis Web," Insan Pembangunan Sistem Informasi, vol. 8, no. 1, 2020.

[10] R. Susanti, S., Junianto, E., \& Rachman, "Implementasi Framework Laravel Pada Aplikasi Pengolah Nilai Akademik Berbasis Web," J. Inform. UBSI, vol. 4, no. 1, pp. 108117, 2017.

[11] M. Charis, "Sistem Informasi Pengelolaan Surat Masuk Dan Keluar Dengan Visual Foxpro 8.0," J. Tek. Unisfat, vol. 5, pp. 22-30, 2009.

[12] I. K. Dewi, "Pengelolaan Administrasi Surat Masuk dan Keluar Unit Kerja BAAK Berbasis Web," J. Sist. Inf. dan Manaj., vol. 7, pp. 55-64, 2019.

[13] S. Mardiyati, "Sistem Pengelolahan Data Surat Masuk Dan Surat Keluar Kelurahan Curug," J. Inov. Inform. Univ. Pradita, vol. V, no. 58, pp. 11-23, 2020.

[14] R. Wahyuni and Y. Irawan, "Aplikasi Pengarsipan Surat Masuk dan Surat Keluar Berbasis Web pada SMP Negeri 32 Pekanbaru," J. Teknol. Sist. Inf. dan Apl., vol. 3, no. 4, pp. 252-264, 2020. 